\title{
Project Portfolio Management in the Front-End of Innovation of Research Centers: a Literature Review
}

\author{
Rui Nuno Castro, João José Pinto Ferreira
}

\begin{abstract}
(I Effective portfolio management is vital to successful product innovation. Portfolio management is about making strategic choices. It is about resource allocation. It focuses on project selection. And it deals with balance. "
\end{abstract}

Robert G. Cooper, Scott J. Edgett, and Elko J. Kleinschmidt

\begin{abstract}
The beginning of an innovation process, also known as "front-end of innovation" (FEI), counts as an essential contributor to the successful development of new products and for their market appeal. Nevertheless, while helpful procedures and techniques for developing new products are well-known and widely applied, FEI is still an understudied area, and models for managing it are not yet commonly used in technology-oriented companies. FEI, also known as "fuzzy front end", can even be "fuzzier" in not-for-profit research centers. That is because the focus of these centers is advancing of scientific knowledge, rather than commercializing the results of those activities. This study summarizes the insights from a literature review on the topic of "project portfolio management" (PPM) in relation to innovation and, more specifically, with FEI and its components of ideation, innovation management, innovation strategy, foresight, and incremental or radical innovation. The authors selected and reviewed content from 170 papers published in SCOPUS prior to February 2019. The discussion uses a theoretical framework called "Front-End of Innovation Integrative Ontology (FEI2O)" to assist in framing the discussion.
\end{abstract}

\section{Introduction}

This study presents an integrative literature review on the processes, techniques, and capabilities of managing project portfolios, and on how they are discussed from the perspectives of innovation, ideation, and dynamic capabilities. The relationship among these topics is described in the scope of not-for-profit research centers. This study aims at addressing the problem of selecting and identifying the "best" opportunities in not-for-profit research centers that aim to impact society by transferring their R\&D results to business enterprises. The purpose of not-for-profit research centers, as the name suggests, is different from that of for-profit companies. Companies target profit generation and thus innovation gets motivated by an expectation to increase sales and revenues. Not-for-profit research centers, on the other hand, are typically funded by public state budgets. They have a mission to advance knowledge, train researchers, and explore areas that may not be profitable in the short or even medium-term. However, most of these research entities seek to promote close relationships with companies, and thus enable knowledge and technology transfers.

The topic of "project portfolio management" (PPM) has been discussed and researched over the past 50 to 60 years (Zschocke et al., 2014). PPM is typically described as a process to attain four main objectives: maximize the value of a portfolio of projects, attain a balanced portfolio, make sure projects are strategically aligned, and develop the right number of projects to fit the existing resources (Cooper \& Edgett, 2014). PPM targets the successful execution and development of active projects, while maintaining a balanced portfolio according to a suitable organizational strategy, with the right number of active projects and maximizing the value of the portfolio. PPM is well-established in the 


\section{Project Portfolio Management in the Front-End of Innovation of Research Centers: a Literature Review}

\section{Rui Nuno Castro \& João José Pinto Ferreira}

"new product development" (NPD) phase (Cooper et al., 2001) and already well understood in the scope of companies that develop radical or incremental products. It is less studied and applied by companies that develop new services (Aas et al., 2017), and research on the use of PPM by not-for-profit organizations still seems to be nonexistent (Barczak et al., 2006).

Not-for-profit research centers do not usually develop tangible commercial products. The "product" of a research center is commonly intangible and takes the "shape" of "intellectual property" (IP). Thus, new research projects may have several goals: to develop new IP for transferring/integrating into third party's commercial products in the future, to develop new technical and scientific competences and knowledge (thus contributing to the advancement of science and knowledge), or to develop new solutions, products, or services jointly with companies. Consequently, applying a PPM process in not-for-profit research centers may not be adequate. For example, many projects in this type of organization are publicly funded and cannot be canceled. These factors need to be considered, and research is required to find out how to adapt a PPM process to this reality. Also, the connection between the success of front-end activities and overall project success is not yet well understood (Kock et al., 2016).

Within the above context, this review article aims at understanding how to effectively manage a large number of ideas and opportunities that appear in the "front-end of innovation" (FEI) of not-for-profit R\&D Centers. We present a literature review on the PPM topic that related organizational capability with the topic of "innovation". Specifically, we focus on FEI and its components of ideation, innovation management, innovation strategy, foresight, and incremental or radical new products. The paper's goals are: 1) to assess the available literature on both PPM and FEI, and identify insights that could be valuable to the specific context of not-for-profit research centers, 2) to discover the most relevant discussion threads relating to these topics, 3) to discover the existing gaps in the literature, 4) to unfold new research directions pointed by the authors of previous studies, and 5) to use an existing framework to organize all of the involved concepts.

This study is based on a selection and review of content in 170 publications concerning PPM and its relationship with FEI in the scope of not-for-profit research centers. The search included all available papers published in
SCOPUS until February 2019. The discussion uses the so-called "Front-End of Innovation Integrative Ontology (FEI2O)" framework (Pereira et al., 2020) as a theoretical tool to assist in framing the problem. This paper writes through the use of reviews as proposed by Post, Sarala, Gatrell, and Prescott (2020), which involves looking at reviews as one possible "avenue" for advancing beneficial theory.

The paper contains five sections. The next section describes the research approach, followed by findings from the literature review in the subsequent section. Then a discussion of findings is presented, along with conclusions and ideas for further research to close to the paper.

\section{Research Method}

This study follows the "integrative literature review" approach defined by Torraco (2005). As a result, our review shows diversity and depth in the topics approached by this field. It intends to offer a novel and distinctive contribution to theory (Lepine \& Wilcox-King, 2010 ) by relating the PPM process with FEI in not-forprofit research centers, thereby laying the ground for further development in this area.

\section{Data collection process}

Several methodologies may be used to collect data for a literature review (Crossan \& Apaydin, 2010). We chose to search the Scopus database for keywords using queries shown in Table 1. Successive searches \#1, \#2, and \#3 were done to cover different possible perspectives for paper selection. The whole process resulted in a total of 170 peer-reviewed articles, which are used in this review.

\section{Data organization, classification, and results}

We organized the articles in an electronic spreadsheet, ordered by number of citations, and categorized according to the contents of abstracts. The review was structured in a concept matrix as recommended by Webster and Watson (2002). The selected concepts were also used in the database queries. The concept of "innovation" was split as illustrated in the concept matrix outline in Figure 1. Several other words were also found to be associated with innovation. Their usage was less frequent, so we grouped them under the concept of "other innovation topics". The frequency table used in Figure 2, as suggested by Linnenluecke and Marrone (2019), shows the number of articles found per concept. 


\section{Project Portfolio Management in the Front-End of Innovation of Research Centers: a Literature Review}

\section{Rui Nuno Castro \& João José Pinto Ferreira}

We continued this analysis by uncovering relationships among concepts, as a way to find out if one concept appears in the literature more often related to another concept. Such relationships may indicate that certain concepts cannot be dissociated from other concepts, and thus that discussions of the PPM literature need to consider multiple concepts, an approach suggested by Tranfield, Denyer, and Smart (2003). We derived the results using an aggregative approach to try to identify emerging themes. Table 2 shows the number of articles that discuss PPM with two other concepts simultaneously.

The acronyms in Table 2 stand for: ID -ideation, MGMT - management, ST - strategy, NPD - new product development, FS - foresight, FEI - front-end of innovation, INC/RAD -incremental or radical, OIT other innovation topics, DC - dynamic capabilities, RC research center

\section{Literature Review}

We grouped the papers based on the concepts that are jointly discussed at least three times in the bibliographic database. The discussion follows the columns of Table 2 . Below we identify the main threads of discussion in each group of related concepts that we found in the papers. Each group of concepts may have one or more threads of discussion.

\begin{tabular}{|c|c|}
\hline Search & Query \\
\hline 1 & $\begin{array}{l}\text { (KEY ( portfolio management) AND TITLE-ABS-KEY ("front-end" } \\
\text { or "innovation" OR "ideation" oR "research center" OR "nonprofit" oR "not-for- } \\
\text { profit")) AND DOCTYPE (af) AND (LIMIT-TO (SUBJAREA, "BUSI") OR LIMIT- } \\
\text { TO (SUBJAREA, "ENGI") OR LIMIT-TO (SUBJAREA, "DECI") OR LIMIT- } \\
\text { TO (SUBJAREA, "SOCI") OR LIMIT-TO (SUBJAREA, "COMP")) AND (LIMIT- } \\
\text { TO (LANGUAGE, "English")) } \\
\text { Results: } 161 \text { articles, most hits were related to the word "Innovation". Innovation is a very used and } \\
\text { generic term, frequently associated with topics like "monagement", "strategy", "new product } \\
\text { development", "foresight", "front-end", "incremental or rodical", "IP management", among many } \\
\text { others. }\end{array}$ \\
\hline 2 & $\begin{array}{l}\text { (KEY ( portfolio AND management OR innovation) AND TITLE-ABS- } \\
\text { KEY ("ideation" OR "research center" OR "nonprofit" OR "not-for-profit" OR "R\&D } \\
\text { organization")) AND (LIMIT-TO (DOCTYPE, "ar")) AND (LIMIT- } \\
\text { TO (SUBJAREA, "BUSI") OR LIMIT-TO (SUBJAREA, "ENGI") OR LIMIT- } \\
\text { TO (SUBJAREA, "SOCI") OR LIMIT-TO (SUBJAREA, "COMP") OR LIMIT- } \\
\text { TO (SUBJAREA, "DECI")) AND (LIMIT-TO (LANGUAGE, "English")) } \\
\text { The word "front-end" was removed from Search \#1 and "Innovation" was moved to just } \\
\text { keywords. The term "R\&D organization" was added to expand the search. } \\
\text { Results: } 16 \text { articles, out of which } 11 \text { were already in the results of search \#1. The remaining } 5 \\
\text { were added to the initial list. }\end{array}$ \\
\hline 3 & $\begin{array}{l}\text { (KEY ( portfolio management) AND TITLE-ABS-KEY ("front-end" } \\
\text { or "innovation" OR "ideation" OR "research center" OR "nonprofit" oR "not-for-profit" OR } \\
\text { "research institute" OR "university")) AND DOCTYPE (ar) AND (LIMIT- } \\
\text { TO (SUBJAREA, "BUSI") OR LIMIT-TO (SUBJAREA, "ENGI") OR LIMIT- } \\
\text { TO (SUBJAREA, "DECI") OR LIMIT-TO (SUBJAREA, "SOCI") OR LIMIT- } \\
\text { TO (SUBJAREA, "COMP")) AND (LIMIT-TO (LANGUAGE, "English")) } \\
\text { Search \#1 was given another variation now including the terms "research institute" or } \\
\text { "university". } \\
\text { Results: } 220 \text { articles. After checking the abstracts, only four were added to the initial list. }\end{array}$ \\
\hline
\end{tabular}

Table 1. Data collection queries performed in Scopus 


\section{Project Portfolio Management in the Front-End of Innovation of Research Centers: a Literature Review}

\section{Rui Nuno Castro \& João José Pinto Ferreira}

Figure 1. Sample Concept Matrix

\begin{tabular}{|c|c|c|c|c|c|c|c|c|c|c|}
\hline \multirow[t]{3}{*}{ Articles } & \multicolumn{10}{|c|}{ PPM Concepts } \\
\hline & \multirow[b]{2}{*}{ 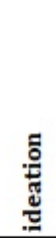 } & \multicolumn{7}{|c|}{ innovation } & \multirow[b]{2}{*}{ 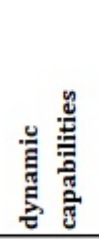 } & \multirow[b]{2}{*}{ 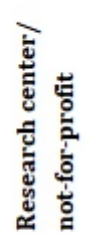 } \\
\hline & & 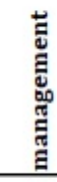 & 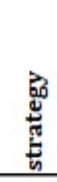 & 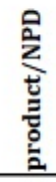 & 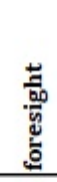 & 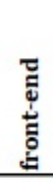 & 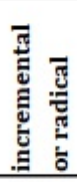 & 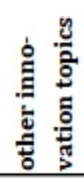 & & \\
\hline \begin{tabular}{|l} 
Cooper, R. G., Edgett, S. J., \& \\
Kleinschmidt, E. J. (2001). New \\
Product Portfolio Management \\
for New Product Development: \\
Results of an Industry Practices \\
Study. R\&D Management, 31(4).
\end{tabular} & & & & $\mathrm{x}$ & & & & & & \\
\hline $\begin{array}{l}\text { Cooper, R. G., Edgett, S. J., \& } \\
\text { Kleinschmidt, E. J. (2004). } \\
\text { Benchmarking best NPD } \\
\text { practices-II. Research- } \\
\text { Technology Management, 47(3) } \\
\text { 50-59. }\end{array}$ & & & $\mathrm{x}$ & & & & & & & \\
\hline $\begin{array}{l}\text { Mikkola, J. H. Portfolio } \\
\text { management of R\&D projects: } \\
\text { implications for innovation } \\
\text { management, Technovation } 21 \\
\text { (2001) 423-435 }\end{array}$ & & $\mathrm{x}$ & & & & & & & & \\
\hline$(\ldots)$ & $(\ldots)$ & $(\ldots)$ & $(\ldots)$ & $(\ldots)$ & $(\ldots)$ & $(\ldots)$ & $(\ldots)$ & $(\ldots)$ & $(\ldots)$ & $(\ldots)$ \\
\hline
\end{tabular}

1. Relationship between the group of concepts PPM, Ideation, and Innovation Management

Farrington, Henson, and Crews (2012) related concepts with foresight methods and discussed how these methods influence the strategic research agenda of organizations. Khameneh, Sobhiyah, and Hosseini (2016) proposed a PPM capability model where idea and proposal management is a critical capability. In another paper, from an anonymous author (2003), it was mentioned that as much as $88 \%$ of initial screening

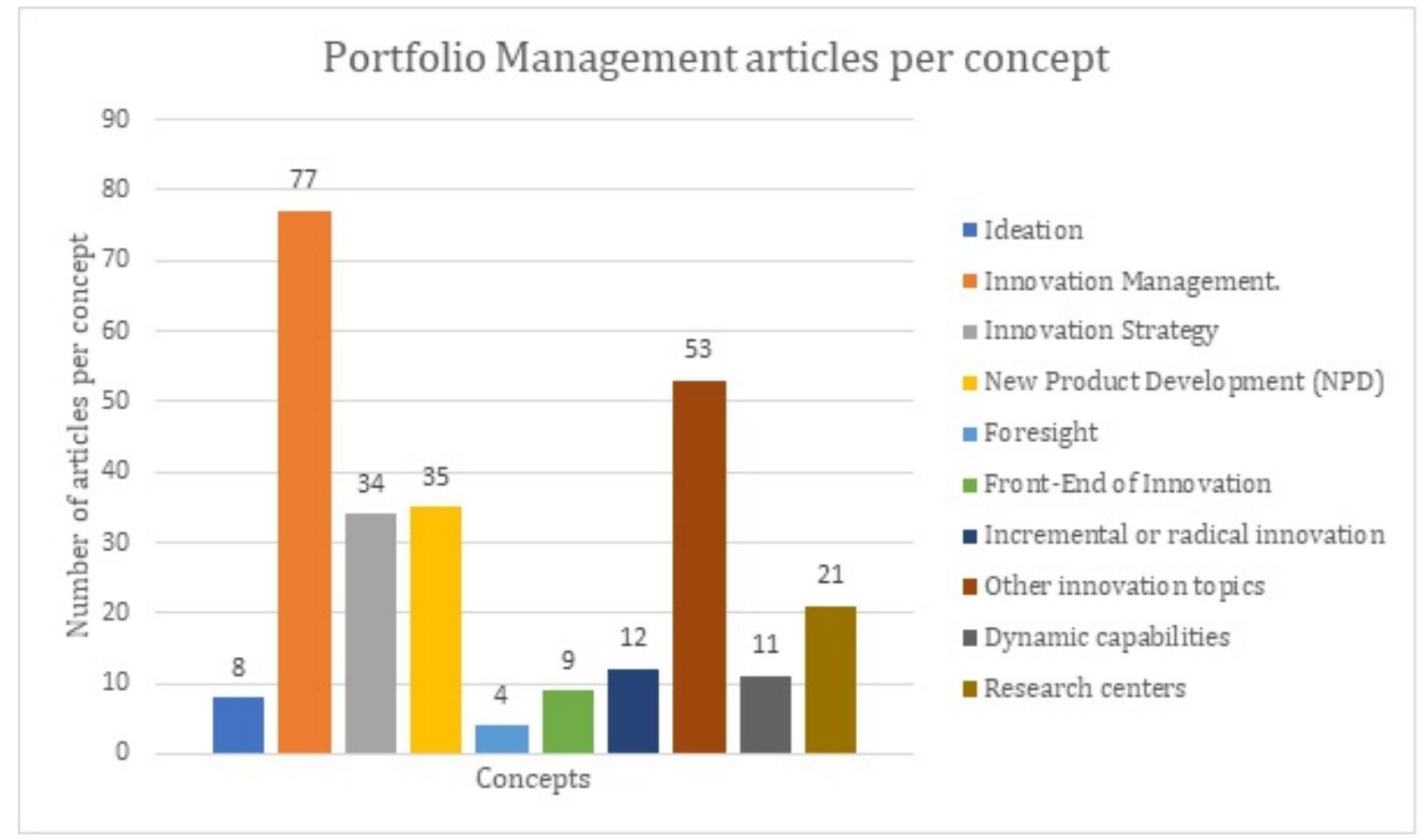




\section{Project Portfolio Management in the Front-End of Innovation of Research Centers: a Literature Review}

Rui Nuno Castro \& João José Pinto Ferreira

Table 2. Number of articles discussing PPM with two other concepts

\begin{tabular}{|l|r|r|r|r|r|r|r|r|r|r|}
\hline & ID & MGMT & ST & NPD & FS & FEI & INC/RAD & OIT & DC & \multicolumn{1}{c|}{ RC } \\
\hline ideation & & 3 & 1 & 2 & 1 & 3 & 1 & 0 & 1 \\
\hline management & 3 & & 19 & 19 & 2 & 1 & 7 & 9 & 6 \\
\hline strategy & 1 & 19 & & 6 & 1 & 2 & 4 & 2 & 4 \\
\hline product/NPD & 2 & 19 & 6 & & 0 & 3 & 3 & 2 & 2 \\
\hline foresight & 1 & 2 & 1 & 0 & & 0 & 1 & 0 & 0 \\
\hline front-end & 3 & 1 & 2 & 3 & 0 & & 0 & 0 & 1 \\
\hline incremental or radical & 1 & 7 & 4 & 3 & 1 & 0 & & 0 & 1 \\
\hline other inno-vation topics & 0 & 9 & 2 & 2 & 0 & 0 & 0 & 1 \\
\hline dynamic capabilities & 1 & 6 & 4 & 2 & 0 & 1 & 1 & 6 & \\
\hline Research center/not-for-profit & 0 & 8 & 5 & 0 & 1 & 1 & 1 & 2 \\
\hline
\end{tabular}

decisions made on new product projects are deficient and proposed that knowledge management solutions can enhance business performance. These findings suggest that ideation and knowledge management serve as critical capabilities of the PPM process and can have a positive influence on a company's strategic research agenda. This is the main thread of discussion found among this group of concepts.

\section{Relationship between the group of concepts PPM, \\ Ideation, and Front-End of Innovation}

Three articles discussed this topic. The authors focused on the topic of ideation portfolio management, how it affects front end performance, and how it eventually impacts the PPM process. Heising (2012) proposed a framework that shows the relationship between ideation and PPM, while Kock, Heising, and Gemünden (2015) addressed an identified research gap ("how the management of ideation affects project performance") by performing an empirical cross-industry investigation. Kock, Heising, and Gemünden (2016) further discussed how researchers tend to explore the front-end from a single project perspective, instead of from a holistic perspective. The contribution of ideation portfolio management to the success of FEI activities marks a common thread of discussion found in the literature.

\section{Relationship between the group of concepts PPM, Innovation Management, and Innovation Strategy}

This relationship was addressed by nineteen articles. The coordination of collaborative projects and open innovation is a thread discussed by Katzy, Turgut, Holzmann, and Sailer (2013) and Brocke and Lippe (2015), which revealed that project managers tend to fail in satisfying the needs of collaborative projects. Several authors have discussed a thread on the alignment of projects with business strategy (Chao et al., 2009; de Moraes \& Augusta Varela, 2013; Khameneh et al., 2016; Haghighi Rad \& Rowzan, 2018). Other authors have argued, on another discussion thread, about how workshop-based road-mapping techniques may be used to address multiple management challenges, and integration in an organization's "innovation business plan” (Farrokhzad et al., 2008; Phaal et al., 2012).

\section{Relationship between the group of concepts PPM,} Innovation Management, and New Product Development (NPD)

Nineteen articles also addressed this theme. A first thread of discussion is on the efficiency of $R \& D$ investments. Chao and Kavadias (2013) discussed the trade-off between how much is invested and how a firm invests money (the firm's NPD portfolio strategy). Hughes and Chafin (1998) proposed a "value proposition life cycle" to improve the efficiency of multifunctional project teams. Schultz, Salomo, and Talke (2013) offered a scale to measure portfolio innovativeness, while Beaume, Maniak, and Midler (2009) put forward an innovation management life-cycle framework to measure the interplay between new features and new products. The topic of knowledge management is another discussion thread addressed by Cormican and O'Sullivan (2003), who focused on how to convert a company's knowledge base into IP and new products, and on the implications of a knowledge-intensive economy on networked organizations (Cormican \& O’Sullivan, 2004).

The third thread within this group of concepts unfolds on the quality of decision making. Decision making in 


\section{Project Portfolio Management in the Front-End of Innovation of Research Centers: a Literature Review}

Rui Nuno Castro \& João José Pinto Ferreira

PPM and how it is influenced by the personalities and styles of the decision-makers was discussed by Kock and Gemünden (2016) while the same problem was addressed in family firms by Kraiczy, Hack, and Kellermanns (2015). Other authors studied the decisionmaking process in electronics companies (Jugend et al., 2015), and checked the role of incentives and collaborative tasks in decision making (HutchisonKrupat \& Kavadias, 2018).

The last thread presents PPM as a capability to reduce time-to-market and managing scope. Ferrarese and De Carvalho (2014) proposed a tool to maximize the effective time-to-market of a portfolio given the competitive monitoring activities, and Abrantes and Figueiredo (2014) identified the challenges to manage the scope of NPD projects within the dynamic contexts that organizations face today. Country-based PPM practices in developing countries were analyzed by authors bringing forward recommendations for establishing or improving PPM capabilities in those countries' organizations (Jugend et al., 2016; Khameneh et al., 2016).

\section{Relationship between the group of concepts PPM, Innovation Management, and Incremental/Radical Innovation}

Seven articles addressed this theme. The main thread of discussion in these papers was resource allocation to projects developing either radical new products or incremental new features. Similarly, the influence was shown of public incentives in the allocation of resources between projects that improve products (incremental innovation) and develop new products (radical innovation) (Chao et al., 2009). Another point of view compared how monopoly firms and their competing firms address the same problem (Zschocke et al., 2014). Other authors have offered a qualitative contribution to resource allocation based on multiple case studies (Lettice \& Thomond, 2008). Finally, a discussion thread on the importance of continuous innovation as a method to battle against competitor's disruptive innovations was highlighted as another aspect under consideration (Hughes \& Chafin, 1998; Denning, 2012).

\section{Relationship between the group of concepts PPM, Innovation Management and Dynamic Capabilities} The management of collaborative projects and open innovation as strategic organizational capabilities was a thread discussed by Katzy et al. (2013) who identified a gap in coordinating open innovation. These authors state that such collaboration presents specific challenges that demand adaptations and adjustments to existing project management approaches. On another thread, PPM was considered as having a holistic capability to align projects with business strategy by Khameneh et al. (2016). These authors propose a PPM capability model that consists of eleven areas, with 81 capabilities. Other authors have treated "novelty" as a multidimensional construct (Rosenkopf \& McGrath, 2011; Urhahn \& Spieth, 2014; Sicotte et al., 2015). Building on the dynamic capabilities' theory, these authors discuss the implications of portfolio innovativeness.

\section{Relationship between the group of concepts PPM, Innovation Management and Research Centers}

This relationship was debated in eight articles. The first thread discussed the management of collaborative projects as expressions of academia-industry interaction (Katzy et al., 2013; Brocke \& Lippe, 2015). One recommendation for future research on this topic suggested that effective mechanisms are needed for project collaboration between NRIs (National Research Institutes) and for-pro $t$ organizations to maximize bene ts for both parties (Jeng \& Huang, 2015). Another thread of discussion was resource allocation to projects as a trade-off between incremental and radical innovation (Hendriks et al., 1999; Chao et al., 2009). On a third thread within this group of concepts, some papers have presented portfolio-building processes for evaluating project portfolios at the early initiation stage in public and not-for-profit research organizations (Pereira \& Veloso, 2009; Jeng \& Huang, 2015). Finally, a systematic management method for interdisciplinary research at an academic research institution-level using a co-citation index was also proposed (Kodama et al., 2013).

\section{Relationship between the group of concepts PPM, Innovation Strategy, and NPD}

This relationship was discussed in six articles. The single thread of discussion was on the efficiency of $R \& D$ investments. On the efficiency of PPM processes, Cooper, Edgett, and Kleinschmidt (2002), and the same authors (2000) described the importance of a Stage-Gate model, and how its correct application increases a portfolio's value. Other authors contributed to this discussion through aligning $R \& D$ intensity with NPD portfolio efficiency, together with multifunctional project teams (Hughes \& Chafin, 1998; Chao \& Kavadias, 2013). 


\section{Project Portfolio Management in the Front-End of Innovation of Research Centers: a Literature Review}

\section{Rui Nuno Castro \& João José Pinto Ferreira}

9. Relationship between the group of concepts PPM, Innovation Strategy, and Incremental/Radical Innovation

Four articles addressed this relationship. The authors addressed ways for companies to battle disruptive innovation brought up by other companies and consider alternative strategies. Denning (2012) compared continuous innovation with "good" management and concluded that continuous innovation is the most reliable strategy. Chao and Kavadias (2008) discussed, on another thread, the definition of a portfolio strategy that balances projects between incremental and radical innovation. Weigel and Goffin (2015) argued about the

Table 3. List of discussion threads identified in the literature review

\begin{tabular}{|c|c|c|c|c|c|c|c|}
\hline ID Groups of concepts & Discussion thread & $\mid$ & $\sum_{i=1}$ & 이 & ஜி & 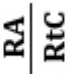 & $\theta$ \\
\hline 1 PPM, Ideation \& Innovation Mgmt. & $\begin{array}{l}\text { Ideation and knowledge management are } \\
\text { critical capabilities of the PPM process }\end{array}$ & & & $\mathrm{x}$ & & & \\
\hline 2 PPM, Ideation \& the FEI & $\begin{array}{l}\text { The contribution of ideation portfolio } \\
\text { management to the success of the activitie } \\
\text { in the Front-End of Innovation }\end{array}$ & & & $\mathrm{x}$ & & & \\
\hline \multirow[t]{2}{*}{$\begin{array}{l}3 \text { PPM, Innovation Mgmt. \& } \\
\text { Innovation Strategy }\end{array}$} & $\begin{array}{l}\text { Coordination of collaborative projects and } \\
\text { open innovation }\end{array}$ & $\mathrm{x}$ & & & & & \\
\hline & $\begin{array}{l}\text { Alignment of projects with the business } \\
\text { strategy }\end{array}$ & & & & $\mathrm{x}$ & & \\
\hline \multirow[t]{4}{*}{4 PPM, Innovation Mgmt. \& NPD } & The efficiency of investments in R\&D & & $\mathrm{x}$ & & & & \\
\hline & Knowledge management & & & $\mathrm{x}$ & & & \\
\hline & Quality of decision making & & & & & & $\mathrm{x}$ \\
\hline & $\begin{array}{l}\text { PPM as a capability to reduce time-to- } \\
\text { market and managing scope }\end{array}$ & & $\mathrm{x}$ & & & & \\
\hline \multirow[t]{2}{*}{5} & $\begin{array}{l}\text { Resource allocation to projects developing } \\
\text { n radical new products or developing } \\
\text { incremental new features }\end{array}$ & & & & & $\mathrm{x}$ & \\
\hline & $\begin{array}{l}\text { Continuous innovation to battle against } \\
\text { competitor's disruptive innovations. }\end{array}$ & & & & & $\mathrm{x}$ & \\
\hline \multirow[t]{2}{*}{$\begin{array}{l}6 \text { PPM, Innovation Mgmt. \& Dynamic } \\
\text { capabilities }\end{array}$} & $\begin{array}{l}\text { Management of collaborative projects and } \\
\text { open innovation }\end{array}$ & $\mathrm{x}$ & & & & & \\
\hline & $\begin{array}{l}\text { PPM as a holistic capability to align } \\
\text { projects with business strategy }\end{array}$ & & & & $\mathrm{x}$ & & \\
\hline \multirow{3}{*}{$\begin{array}{l}7 \text { PPM, Innovation Mgmt. \& Research } \\
\text { Centers }\end{array}$} & The management of collaborative projects & $\mathrm{x}$ & & & & & \\
\hline & Resource allocation to projects & & & & & $\mathrm{x}$ & \\
\hline & $\begin{array}{l}\text { Evaluating a project portfolio at the early } \\
\text { initiation stage in public and not-for-profit } \\
\text { research organizations }\end{array}$ & & $\mathrm{x}$ & & & & \\
\hline 8 PPM, Innovation Strategy \& NPD & The efficiency of the investments in R\&D & & $\mathrm{x}$ & & & & \\
\hline \multirow[t]{2}{*}{$\begin{array}{l}9 \text { PPM, Innc } \\
\text { Incremen }\end{array}$} & $\begin{array}{l}\text { Alternatives to battle counter disruptive } \\
\text { n innovation }\end{array}$ & & & & & $\mathrm{x}$ & \\
\hline & $\begin{array}{l}\text { Portfolio strategy that balances the } \\
\text { projects between incremental and radical } \\
\text { innovation }\end{array}$ & & & & & $\mathrm{x}$ & \\
\hline \multirow[t]{2}{*}{$\begin{array}{l}10 \text { PPM, Innovation Strategy \& } \\
\text { Research Centers }\end{array}$} & $\begin{array}{l}\text { Management of collaborative projects as } \\
\text { forms of academia-industry interaction }\end{array}$ & $\mathrm{x}$ & & & & & \\
\hline & $\begin{array}{l}\text { Selection and prioritization of IT projects } \\
\text { in universities }\end{array}$ & & $\mathrm{x}$ & & & & \\
\hline 11 PPM, NPD, and the FEI & $\begin{array}{l}\text { Relate portfolio Management and new } \\
\text { product development with the Front-End } \\
\text { of Innovation }\end{array}$ & & & $\mathrm{x}$ & & & \\
\hline $\begin{array}{l}12 \text { PPM, NPD \& Incremental and } \\
\text { Radical Innovation }\end{array}$ & $\begin{array}{l}\text { Balance between incremental and radical } \\
\text { innovation projects }\end{array}$ & & & & & $\mathrm{x}$ & \\
\hline
\end{tabular}




\section{Project Portfolio Management in the Front-End of Innovation of Research Centers: a Literature Review}

\section{Rui Nuno Castro \& João José Pinto Ferreira}

importance that accessing customer insights assumes in creating radical new products, services, and business models.

\section{Relationship between the group of concepts PPM,} Innovation Strategy, and Research Centers

Five papers related these concepts. The management of collaborative projects as forms of academia-industry interaction is a thread discussed by Katzy et al. (2013) and by Brocke and Lippe (2015). Another thread of discussion was on approaches for selecting and prioritizing IT projects in universities (Kauffmann et al., 1999; Ahriz et al., 2018). According to these authors, such approaches need to be adapted to the university's strategy, vision, and culture because university managers face many uncertainties when prioritizing projects that make up their portfolio.

\section{Relationship between the group of concepts PPM, NPD, and FEI}

Three papers discussed this topic. The discussion stated that the relationship with the success of the FEI is not yet fully understood (Kock et al., 2016). Cooper (2006) had previously discussed the adoption of the Stage-Gate process by technology-development companies to support front-end activities. Oliveira \& Rozenfeld (2010) presented a new method to support the development of front-end activities based on PPM together with technology road-mapping (TRM). Oh, Yang, and Lee (2012) proposed a decision-making framework that uses a fuzzy expert system in PPM to deal with the uncertainty of fuzzy front-end product development.

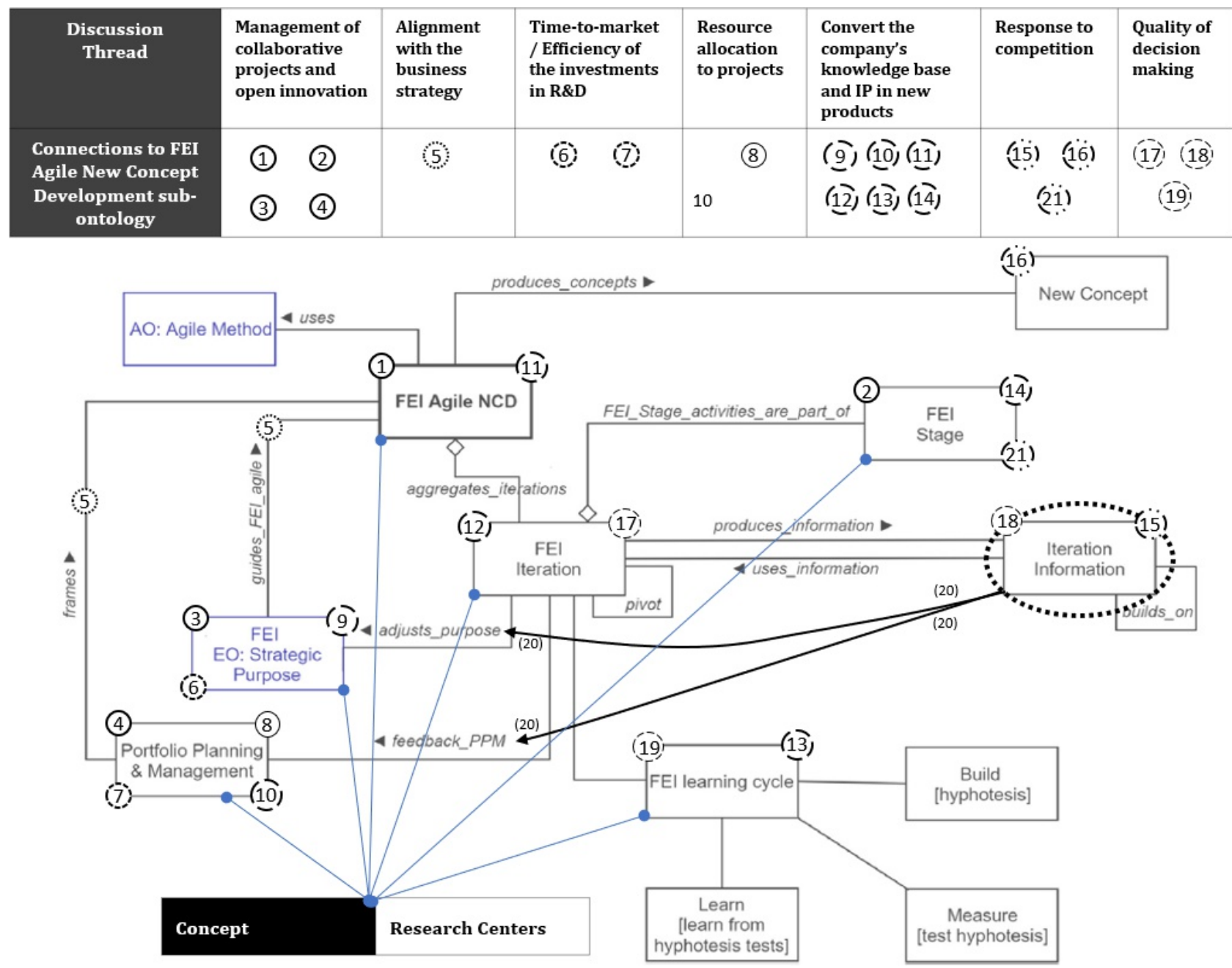

Figure 3. The connections between the PPM discussion threads projected into the FEI Agile New Concept Development sub-ontology - light grey as background (A.R. Pereira et al., 2020) 


\section{Project Portfolio Management in the Front-End of Innovation of Research Centers: a Literature Review}

Rui Nuno Castro \& João José Pinto Ferreira

\section{Relationship between the group of concepts PPM, NPD, and Incremental/Radical Innovation}

Three papers talked about this relation. The balance between incremental and radical innovation projects was the main thread discussed. This thread notes that companies face difficulties in fulfilling a balance of portfolio products, and that these difficulties possibly relate to a concentration of incremental innovation efforts in NPD (Jugend \& Leoni, 2015). An innovation management life-cycle framework was proposed to measure the interplay between new features and new products (Beaume et al., 2009). The role played by PPM in decision-making to invest in high-risk projects and how companies choose to make investments in $R \& D$ was considered critically by Cooper (2013).

\section{Discussion}

We organized the main threads found in the literature review in Table 3. We identified a total of 25 discussion threads out of the 12 concept groups, though some threads appear repeatedly in the different concept groups. Thus, we grouped the 25 threads into an even number of main discussion lines. Together with this a total of seven distinct discussion threads were identifiable in Table 3.

Even though PPM is a well-known organizational capability that has been widely applied in the NPD phase, its relationship with FEI activities is not yet fully understood (Kock et al., 2016). To contribute to rationalizing this relationship, in this discussion we use the FEI Integrative Ontology (FEI2O) proposed by Pereira et al. (2020) to frame the above findings. The FEI2O consists of a set of six sub-ontologies: FEI Purpose, FEI Portfolio Planning \& Management, FEI Agile New Concept Development, FEI Stage, FEI HighLevel, and FEI Actors.

The following discussion will be built around FEI2O's sub-ontology FEI Agile New Concept Development (Figure 3) as the framework with which to overlay the above identified discussion threads. The agile nature of FEI emphasizes the need for flexibility with changing requirements and to adjust for developed concepts. It is described as an iterative process that unfolds along FEI Iterations, resulting in the development of new concepts (Pereira et al., 2020).

The connections between the identified discussion threads and the FEI Agile NCD sub-ontology are described next. The FEI Agile NCD sub-ontology produces the [NEW CONCEPT] that will enter NPD for further commercialization. The development of new concepts in FEI is guided by the [FEI EO: Strategic Purpose] (that represents the organization's strategy) and is framed by the [Portfolio Planning \& Management] process that sets and monitors the constraints for developing new concepts. The [FEI Agile NCD] aggregates iterations [FEI Iteration] that are composed of several [BUILD], [MEASURE], and [LEARN] cycles (the [FEI learning cycle]). These cycles represent the process of building new hypotheses, testing the new hypothesis, and learning from the results of the tested hypothesis. Each iteration builds on previously existing information [Iteration information] and produces new information that will be used in subsequent iteration cycles. The [FEI STAGE] block represents activities executed in FEI (preliminary opportunity identification, product concept definition, feasibility, project planning and business model development). These activities are part of each [FEI Iteration] (each iteration contributes to improving the outcome of the activities performed in the FEI).

The following addresses the relationship between PPM issues and FEI in Figure 3:

- Discussing the management of collaborative projects and open innovation serves to address research gaps in coordinating open innovation projects and in the academy-industry relationship. The influence of industry in academic projects contributes to shaping the strategic purpose [FEI EO: Strategic Purpose] of research institutes (3) because they benefit from being aligned with industry interests. This influence must also be considered in the [Portfolio Planning \& Management] process (4) to find proper balance with other non-industry projects (for example, by assigning them a higher priority when allocating resources). This interaction also influences [FEI STAGE] (2) activities, for example, through identifying new opportunities, and contributes to new research concepts [FEI Agile NCD] being developed by research centers (1).

- One of the PPM process objectives is to align the running projects with an organization's strategic purpose. Discussing the alignment of PPM processes with business strategy concerns the challenge of aligning what is being done in projects with business realities. In FEI, new ideas generated must also be 


\section{Project Portfolio Management in the Front-End of Innovation of Research Centers: a Literature Review}

\section{Rui Nuno Castro \& João José Pinto Ferreira}

aligned with a organization's overall business strategy before new concepts can be generated that will enter NPD. Therefore, aligning PPM processes with business strategy contributes to guiding the [FEI Agile NCD] (5) and to its framing by [Portfolio Planning \& Management] (5).

- The efficiency of $R \& D$ investments factors in to influence the [FEI EO: Strategic Purpose] (6) and the [Portfolio Planning \& Management] process (7). The new concepts being developed during FEI should contribute to boost sales, in case of companies, or cause an impact on society, by not-for-profit research centers. Researchers have been looking into how to reduce the time to market for innovation while balancing increasing technological complexity (A.R. Pereira et al., 2020). Trade-off thus is available between the innovativeness of each new concept produced during FEI (that might require a higher amount of iterations) and the time to introduce new products resulting from new concepts to market (7).

- Resource allocation to projects deals with finding appropriate distribution of human resources among projects, namely among projects developing radical new products, along with those developing incremental innovations that sustain the current business. While maintaining appropriate resources for incremental innovation projects, the [Portfolio Planning \& Management] process (8) must leave "space" for disruptive projects too.

- Converting an organization's knowledge base and IP into new products is one of the main objectives of activities performed in the [FEI STAGE] (14). Connections (12) [FEI Iteration] and (13) the [FEI learning cycle] represent the relation between existing knowledge and new knowledge being acquired in each FEI iteration, as new knowledge is built upon existing knowledge. The new concepts [FEI Agile NCD] (11) being produced during FEI will aggregate knowledge gained from several iterations and result from a combination of new and previously existing knowledge. As the [FEI Agile NCD] is framed by the [Portfolio Planning \& Management] process, a relation also forms between the existing knowledge base and this process (10). Finally, as each [FEI Iteration] adjusts the [FEI EO: Strategic purpose], the adjusted purpose also gets framed by the existing knowledge base and IP (9).
- The response to competition of a new product/service concept is greatly influenced by the value proposition and its positioning in the market. This gets developed in different FEI stages, including the definition of the business model used to offer the new concept in the market (21). This issue is further related to the balance between "continuous innovation" and "good management" (Denning, 2012). There is a set of internal management decisions that provide new information to each FEI cycle [Iteration information] (15). The response to competition is "materialized" by the new concepts that emerge as the result of the activities performed in the overall FEI process resulting in the [New concept] (16). Both [Portfolio Planning \& Management] and [FEI EO: Strategic Purpose] get insights from the [Iteration information] (20). This feedback is key to adjusting strategy to the positioning of competing products and reacting to opportunities in emerging markets.

- On the quality of decision making, the papers discuss the influence of different personalities and styles on the quality of the decisions that are taken. The iterative process of the FEI and the involvement of multiple actors contributes to soften those influences on new concepts that are developed during FEI. Connections (17) [FEI Iteration], (18) [Iteration information] and (19) [FEI learning cycle] show how decision making is impacted by the information used at the start of each new FEI iteration, the result of each iteration, and the aggregated effect on the FEI Agile NCD. Higher quality decisions taken at this stage typically build on internal knowledge as well as on external primary and secondary sources (for example, FEI learning cycle), higher quality concepts (a.k.a. new knowledge, or new IP, or new prototypes) develop into products, and more likely innovations increase the portfolio's innovativeness. Adequate ideation of portfolio management may also help increase decision quality and reduce the time-tomarket (Heising, 2012), a crucial feature in today's competitive world.

- In research centers, the [New Concept] module could be renamed as [New Research Concept] in order to focus on R\&D efforts. FEI outcomes may be seen as new ideas/concepts whose feasibility still needs to be assessed before entering the [New Research Development] phase. The discussion of not-for-profit research centers appears mostly related to managing 


\section{Project Portfolio Management in the Front-End of Innovation of Research Centers: a Literature Review}

\section{Rui Nuno Castro \& João José Pinto Ferreira}

collaborative projects and open innovation, along with interaction between academia and industry. This interaction influences the research center's [FEI EO: Strategic Purpose] and its [Portfolio Planning \& Management] process. The activities performed by research centers during FEI must address the challenges of collaborative projects and use the information provided by projects in the [BUILD], [MEASURE] and [LEARN] cycles performed at each [FEI ITERATION]. In the end, new research concepts that are investigated will benefit from close interaction with industry, which is represented in Figure 3 by connections between the "Research Institutes" block and the different components of the FEI Agile NCD sub-ontology.

\section{Conclusion and Suggestions for Further Research}

The discussion threads revealed by this study address all aspects considered in the FEI2O Agile NCD subontology: PPM is an organizational capability that makes sure that both existing and new projects are aligned with business strategy. PPM also ensures that resources get allocated according to a defined strategy and that senior management involvement as an organizational factor drives PPM success.

Kock, Heising, and Gemünden (2016) showed that frontend success is highly essential for later project success. We support this conclusion that brings in the importance of ideation portfolio management. These authors underscore the importance of an effective and efficient FEI for project portfolio success in generating the right ideas.

The research also showed that PPM is widely discussed from the perspective of innovation management, innovation strategy, and NPD. PPM has been a research area for over 50 years (Zschocke et al., 2014) and has been one of the critical components of the Innovation Management field. Despite that, it has been a discipline used mostly by private companies (Pereira \& Veloso, 2009) that focus on developing incremental or radical new products. As such, we conducted an integrative literature review to uncover the usage of PPM in research centers and universities because these entities are partnering more and more with companies to develop innovative new products and services.

As shown by Katzy et al. (2013) and Brocke and Lippe (2015), managing collaborative projects as a form of academy-industry interaction is still an understudied area of project management. Traditional project management methods have tended to fail when dealing with the specificities of these types of projects. The same authors point to the need for further research to generalize the findings and to chart the historical development of coordinating innovation processes. Based on the growing importance of open innovation and in cooperation with not-for-profit research centers and companies, we believe future research could be beneficial by promoting a more holistic understanding of how research centers manage their FEI. More specifically, we wish to inquire how research centers prioritize research project ideas, measure the success of front-end activities, and manage collaborative projects with industry.

Our analysis of the various PPM discussion threads framed together with the FEI Agile New Concept Development sub-ontology reveals that existing research does not highlight $R \& D$ as a critically relevant activity for FEI. This constitutes one of the study's main findings, a surprise considering that both the efficiency of $R \& D$ investments and resource allocation to projects were subjects of research. The relevance of R\&D activities for the FEI and the organization of the FEI in research centers is left as a suggestion for further research. 


\section{Project Portfolio Management in the Front-End of Innovation of Research Centers: a Literature Review}

Rui Nuno Castro \& João José Pinto Ferreira

\section{References}

Aas, T.H., Breunig, K.J., \& Hydle, K.M. 2017. Exploring New Service Portfolio Management. International Journal of Innovation Management, 21(6): 1-41. https://doi.org/10.1142/S136391961750044X

Ahriz, S., El, A., Mansouri, K., \& Qbadou, M. 2018. Cobit 5-Based Approach for IT Project Portfolio Management: Application to a Moroccan University. International Journal of Advanced Computer Science and Applications, 9(4).

https://doi.org/10.14569/IJACSA.2018.090416

Barczak, G., Kahn, K.B., \& Moss, R. 2006. An exploratory investigation of NPD practices in nonprofit organizations. Journal of Product Innovation Management, 23(6): 512-527.

https://doi.org/10.1111/j.1540-5885.2006.00221.x

Beaume, R., Maniak, R., \& Midler, C. 2009. Crossing innovation and product projects management: A comparative analysis in the automotive industry. International Journal of Project Management, 27(2): 166-174.

https://doi.org/10.1016/j.ijproman.2008.09.004

Brocke, J. vom, \& Lippe, S. 2015. Managing collaborative research projects: A synthesis of project management literature and directives for future research. International Journal of Project Management, 33(5): 1022-1039.

https://doi.org/10.1016/j.ijproman.2015.02.001

Chao, R.O., \& Kavadias, S. 2008. A Theoretical Framework for Managing the New Product Development Portfolio: When and How to Use Strategic Buckets. Management Science, 54(5): 907921.

https://doi.org/10.1287/mnsc.1070.0828

Chao, R.O., \& Kavadias, S. 2013. R\&D Intensity and the New Product Development Portfolio. IEEE Transactions on Engineering Management, 60(4): 664675.

https://doi.org/10.1109/TEM.2013.2257792

Chao, R.O., Kavadias, S., \& Gaimon, C. 2009. Revenue Driven Resource Allocation: Funding Authority, Incentives, and New Product Development Portfolio Management. Management Science, 55(9): 1556-1569. https://doi.org/10.1287/mnsc.1090.1046

Cooper, R.G. 2006. Managing technology development projects. Research Technology Management, 49(6): 2331. https://doi.org/10.1080/08956308.2006.11657405

Cooper, R.G. 2013. Invited Article: Where Are All the Breakthrough New Products?: Using Portfolio Management to Boost Innovation. ResearchTechnology Management, 56(5): 25-33. https://doi.org/10.1038/ng1790

Cooper, R.G., \& Edgett, S.J. 2014. New Problems, New Solutions: Making Portfolio Management More Effective Portfolio Management for New Products Picking the Winners. 18.
Cooper, R.G., Edgett, S.J., \& Kleinschmidt, E.J. 2000. New problems, new solutions: making portfolio management more effective. Research Technology Management, 43(2): 18-33.

https://doi.org/10.1080/08956308.2000.11671338

Cooper, R.G., Edgett, S.J., \& Kleinschmidt, E.J. 2001. New Product Portfolio Management for New Product Development\%: Results of an Industry Practices Study. R\&D Management, 31(4).

Cooper, R.G., Edgett, S.J., \& Kleinschmidt, E.J. 2002. Optimizing the stage-gate process: What best-practice companies Do-II. Research Technology Management, 45(6): 43-49.

https://doi.org/10.1080/08956308.2002.11671532

Cormican, K., \& O’Sullivan, D. 2003. A collaborative knowledge management tool for product innovation management. International Journal of Technology Management, 26(1): 53.

https://doi.org/10.1504/IJTM.2003.003144

Crossan, M.M., \& Apaydin, M. 2010. A MultiDimensional Framework of Organizational Innovation: A Systematic Review of the Literature. September.

https://doi.org/10.1111/j.1467-6486.2009.00880.x

de Moraes, E.A., \& Augusta Varela, C. 2013. R,D\&I in electric sector: A management model. Journal of Technology Management and Innovation, 8(SPL.ISS.1): 128-139.

https://doi.org/10.4067/S0718-27242013000300067

Denning, S. 2012. The battle to counter disruptive competition: continuous innovation vs "good" management. Strategy \& Leadership, 40(4): 4-11. https://doi.org/10.1108/10878571211242894

Farrington, T., Henson, K., \& Crews, C. 2012. Research Foresights: The Use of Strategic Foresight Methods for Ideation and Portfolio Management. ResearchTechnology Management, 55(2): 26-33. https://doi.org/10.5437/08956308X5502023

Farrokhzad, B., Kern, C., \& Vries, M. De. 2008. Innovation business plan at Siemens: portfolio-based roadmapping to convert promising innovation projects into concrete successes. International Journal of Technology Intelligence and Planning, 4(2): 153. https://doi.org/10.1504/IJTIP.2008.018314

Ferrarese, A., \& De Carvalho, M.M. 2014. Time-to-need: A portfolio tool to balance the time-to-market. Journal of Manufacturing Technology Management, 25(6): 812826.

https://doi.org/10.1108/JMTM-09-2011-0085

Figueiredo, J.R., \& Abrantes, R. 2014. Feature based process framework to manage scope in dynamic NPD portfolios. International Journal of Project Management, 32(5): 874-884.

https://doi.org/10.1016/j.ijproman.2013.10.014

Haghighi Rad, F., \& Rowzan, S.M. 2018. Designing a hybrid system dynamic model for analyzing the impact of strategic alignment on project portfolio 


\section{Project Portfolio Management in the Front-End of Innovation of Research Centers: a Literature Review}

\section{Rui Nuno Castro \& João José Pinto Ferreira}

selection. Simulation Modelling Practice and Theory, 89(May): 175-194.

https://doi.org/10.1016/j.simpat.2018.10.001

Heising, W. 2012. The integration of ideation and project portfolio management - A key factor for sustainable success. International Journal of Project Management, 30(5): 582-595.

https://doi.org/10.1016/j.ijproman.2012.01.014

Hendriks, M.H.A., Voeten, B., \& Kroep, L. 1999. Human resource allocation in a multi-project $R \& D$ environment: Resource capacity allocation and project portfolio planning in practice. International Journal of Project Management, 17(3): 181-188.

https://doi.org/10.1016/S0263-7863(98)00026-X

Hughes, G.D., \& Chafin, D.C. 1998. Turning new product development into a continuous learning process. Journal of Product Innovation Management, 13(2): 89104.

https://doi.org/10.1016/0737-6782(95)00112-3

Jeng, D.J.F., \& Huang, K.H. 2015. Strategic project portfolio selection for national research institutes. Journal of Business Research, 68(11): 2305-2311.

https://doi.org/10.1016/j.jbusres.2015.06.016

Jugend, D., da Silva, S.L., Salgado, M.H., \& Miguel, P.A.C. 2016. Product portfolio management and performance: Evidence from a survey of innovative Brazilian companies. Journal of Business Research, 69(11): 5095-5100.

https://doi.org/10.1016/j.jbusres.2016.04.086

Jugend, D., \& Leoni, J.N. 2015. Product Portfolio Management in Brazilian Technology-based Companies: Case Studies in Medium and Large Companies. Procedia Manufacturing, 3(Ahfe): 65286535.

https://doi.org/10.1016/j.promfg.2015.07.947

Katzy, B., Turgut, E., Holzmann, T., \& Sailer, K. 2013. Innovation intermediaries: a process view on open innovation coordination. Technology Analysis \& Strategic Management, 25(3): 295-309.

https://doi.org/10.1080/09537325.2013.764982

Kauffmann, P., Ricks, W.R., \& Shockcor, J. 1999. Research portfolio analysis using extensions of quality function deployment. EMJ - Engineering Management Journal, $11(2): 3-9$.

https://doi.org/10.1080/10429247.1999.11415021

Khameneh, A., Sobhiyah, M.H., \& Hosseini, S.H.K. 2016. Project portfolio management capability: The case of Iran's power industry innovation projects. International Business Management, 10(12): 23292336. Retrieved from

https://essuir.sumdu.edu.ua/handle/123456789/4635 5

Kock, A., Heising, W., \& Gemünden, H.G. 2016. A Contingency Approach on the Impact of Front-End Success on Project Portfolio Success. Project Management Journal, 47(2): 115-129.

https://doi.org/10.1002/pmj
Kock, A., \& Georg Gemünden, H. 2016. Antecedents to Decision-Making Quality and Agility in Innovation Portfolio Management. Journal of Product Innovation Management, 33(6): 670-686.

https://doi.org/10.1111/jpim.12336

Kock, A., Heising, W., \& Gemünden, H.G. 2015. How ideation portfolio management influences front-end success. Journal of Product Innovation Management, 32(4): 539-555.

https://doi.org/10.1111/jpim.12217

Kodama, H., Watatani, K., \& Sengoku, S. 2013. Competency-based assessment of academic interdisciplinary research and implication to university management. Research Evaluation, 22(2): 93-104.

https://doi.org/10.1007/978-3-642-39112-5-77

Kraiczy, N.D., Hack, A., \& Kellermanns, F.W. 2015. What makes a family firm innovative? CEO risk-taking propensity and the organizational context of family firms. Journal of Product Innovation Management, 32(3): 334-348.

https://doi.org/10.1111/jpim.12203

Lepine, J., \& Wilcox-King, A. (2010). Editors' comments: Developing novel theoretical insight from reviews of existing theory and research. Academy of Management Review, 35(4): 506-509.

https://doi.org/10.5465/AMR.2010.53502455

Lettice, F., \& Thomond, P. 2008. Allocating resources to disruptive innovation projects: challenging mental models and overcoming management resistance. International Journal of Technology Management, 44(1/2): 140 .

https:// doi.org/10.1504/IJTM.2008.020702

Linnenluecke, M.K., \& Marrone, M. 2019. Conducting systematic literature reviews and bibliometric analyses. August.

https://doi.org/10.1177/0312896219877678

Oh, J., Yang, J., \& Lee, S. 2012. Managing uncertainty to improve decision-making in NPD portfolio management with a fuzzy expert system. Expert Systems with Applications, 39(10): 9868-9885.

https://doi.org/10.1016/j.eswa.2012.02.164

Oliveira, M.G., \& Rozenfeld, H. 2010. Integrating technology roadmapping and portfolio management at the front-end of new product development. Technological Forecasting and Social Change, 77(8): 1339-1354.

https://doi.org/10.1016/j.techfore.2010.07.015

Pereira, A.R., Ferreira, J.J.P., \& Lopes, A. 2020. A knowledge representation of the beginning of the innovation process: The Front End of Innovation Integrative Ontology (FEI2O). Data and Knowledge Engineering, 125(November 2019): 101760. https://doi.org/10.1016/j.datak.2019.101760

Pereira, P.L., \& Veloso, F.M. 2009. R\&D activity selection process: Building a strategy-aligned $R \& D$ portfolio for government and nonprofit organizations. IEEE 


\section{Project Portfolio Management in the Front-End of Innovation of Research Centers: a Literature Review}

\section{Rui Nuno Castro \& João José Pinto Ferreira}

Transactions on Engineering Management, 56(1): 95105.

https://doi.org/10.1109/TEM.2008.2009872

Phaal, R., Kerr, C., Oughton, D., \& Probert, D. 2012. Towards a modular toolkit for strategic technology management. International Journal of Technology Intelligence and Planning, 8(2): 161.

https://doi.org/10.1504/IJTIP.2012.048475

Post, C., Sarala, R., Gatrell, C., \& Prescott, J.E. 2020. Advancing Theory with Review Articles. 3117(March). https://doi.org/10.1111/joms.12549

Rosenkopf, L., \& McGrath, P. 2011. Advancing the Conceptualization and Operationalization of Novelty in Organizational Research. Organization Science, 22(5): 1297-1311.

https://doi.org/10.1287/orsc.1100.0637

Schultz, C., Salomo, S., \& Talke, K. 2013. Measuring new product portfolio innovativeness: How differences in scale width and evaluator perspectives affect its relationship with performance. Journal of Product Innovation Management, 30(SUPPL 1): 93-109.

https://doi.org/10.1111/jpim.12073

Sicotte, H., Drouin, N., \& Delerue, H. 2015. Innovation portfolio management as a subset of dynamic capabilities: Measurement and impact on innovative performance. Project Management Journal, 45(6): 5872.

https://doi.org/10.1002/pmj.21456

Torraco, R.J. 2005. Writing Integrative Literature Reviews: Guidelines and Examples. Human Resource Development Review, 4(3): 356-367.

https://doi.org/10.1177/1534484305278283

Tranfield, D., Denyer, D., \& Smart, P. 2003. Towards a Methodology for Developing Evidence-Informed Management Knowledge by Means of Systematic Review. 14: 207-222.

Urhahn, C., \& Spieth, P. 2014. Governing the portfolio management process for product innovation - A quantitative analysis on the relationship between portfolio management governance, portfolio innovativeness, and firm performance. IEEE Transactions on Engineering Management, 61(3): 522533.

https://doi.org/10.1109/TEM.2014.2327254

Webster, J., \& Watson, R.T. 2002. Analyzing the Past to Prepare for the Future: Writing a Literature Review. MIS Quarterly, 26(2): xiii- *xiii.

https://doi.org/10.1.1.104.6570

Weigel, T., \& Goffin, K. 2015. Creating, Innovation Capabilities: Mölnlycke Health Care's Journey. Research-Technology Management, 58(4): 28-35. https:// doi.org/10.5437/08956308X5803324

Zschocke, M.S., Mantin, B., \& Jewkes, E.M. 2014. The effect of competition on R\&D portfolio investments. Production and Operations Management, 23(8): 14391449.

https://doi.org/10.1111/j.1937-5956.2012.01376.x

\section{About the Authors}

Rui Nuno Castro holds a degree in Electrical and Computers Engineering from the Faculty of Engineering, University of Porto (FEUP) since 1996, and a M.Sc. in Digital Communication Systems and Technology from Chalmers University of Technology, in Sweden, in 1999. In 1998-1999 he was a researcher at Ericsson Radio Systems AB in Sweden, where he developed his Master Thesis named "Dynamic Resource Management for Wavelength Division Multiplexing Networks". Between 2000 and 2004, as a researcher at INESC Porto, he actively participated in several projects in the IST framework. Between 2005 and 2010, he was co-founder and Chief Operations Officer at Nonius Software, a Portuguese SME. In 2010, he joined Fraunhofer Portugal as a researcher. He is, since October 2011, R\&D Group Leader at Fraunhofer Portugal. His current research interests are in the field of Innovation and Technology Management.

João José Pinto Ferreira holds a Licenciatura in Electrical Engineering and Computers at Faculty of Engineering, University of Porto (FEUP) in 1987; MSc Electrical Engineering and Computers at FEUP in 1991; Ph.D. in Electrical Engineering and Computers at FEUP in 1995; Habilitation in Industrial Engineering and Management in April 2011. He has held several positions at the FEUP: 1987-1995: Assistant Lecturer; 1995 - 2003: Assistant Professor; 2003-today: Associate Professor. At FEUP (1997-2000) also he was Member of the Executive Board of the Electrical Engineering Department and is, since 2004, the Director of the Master Program of Innovation and Technological Entrepreneurship. Has supervised MSc and Ph.D. students in the areas of Electrical Engineering and Computers, Informatics Engineering and Industrial Engineering and Management. He is Co-Editor-in-Chief and cofounder of the Journal of Innovation Management (http://open-jim.org). His research focuses on the Front-End of Innovation and on its synergies with the early stages of the entrepreneurial activity.

Citation: Castro, R.N., Ferreira, J.J.P. 2020. Project Portfolio Management in the Front-End of Innovation of Research Centers: a Literature Review. Technology Innovation Management Review, 10(12): 46-59. http://doi.org/10.22215/timreview/1409

Keywords: Project Portfolio Management, front-end, innovation, ideation, research center, not-for-profit 